\title{
Temperature and heat flux calculations for the maximum power channel of the TRIGA IAN-R1 research reactor
}

\section{Cálculos de temperatura y flujo de calor para el canal de máxima potencia del reactor de investigación TRIGA IAN-RI}

José Antonio Sarta ${ }^{1}$, Luis Álvaro Castiblanco ${ }^{2}$

Citación: J. A. Sarta y L. A. Castiblanco, “Temperature and heat flux calculations for the maximum power channel of the TRIGA IAN-R1 research reactor", Revista Investigaciones y Aplicaciones Nucleares, n. ${ }^{\circ} 3$, pp. 36-39, 2019. https://doi.org/10.32685/2590-7468/invapnuclear.3.2019.509

Received: August 23, 2019

Accepted: December 16, 2019

Available online: December 30,

2019

Doi: https://doi.org/10.32685/2590-

7468/invapnuclear.3.2019.509

Keywords: temperature, heat flux, departure from nucleate boiling.

Palabras clave: temperatura, flujo de calor, partida de ebullición nucleada.

\section{ABSTRACT}

With cooperation of the International Atomic Energy Agency (IAEA), thermal-hydraulic calculations were carried out for conversion of the IAN-R1 Reactor from MTR-HEU fuel to TRIGA-LEU fuel. To establish thermal-hydraulic calculation and analysis research in Colombia, this program was carried out and included training, acquisition of hardware, software and natural convection flow calculations for the TRIGA IAN-R1 research reactor operating at $100 \mathrm{~kW}$. The purpose of the study is to validate the steady state thermal hydraulic analysis that has been carried out by means of the NATCON code. This paper presents the results of the maximum axial temperature distribution for fuel, clad, and coolant. In addition, the Bernath critical heat flux with pool water temperature as a parameter is presented.

\section{RESUMEN}

En cooperación con el Organismo Internacional de Energía Atómica, se realizaron cálculos termo-hidráulicos en la conversión del Reactor IAN-R1, de combustible MTR de alto enriquecimiento a combustible TRIGA de bajo enriquecimiento. Para establecer investigación y cálculos termo-hidráulicos en Colombia, se adelantó un programa incluyendo entrenamiento, adquisición de equipos y códigos con la realización de cálculos de convección natural para el reactor TRIGA IAN-R1 operando a $100 \mathrm{Kw}$. El propósito del presente estudio es validar el análisis termo-hidráulico en estado estacionario realizado con el código NATCON. Este articulo presenta los resultados de la distribución axial de la temperatura máxima para el combustible, su revestimiento y el refrigerante. Adicionalmente se presenta el flujo de calor crítico de Bernath con la temperatura del agua como parámetro.

\footnotetext{
${ }^{1}$ Pontificia Universidad Javeriana, Departamento de Física, Bogotá, Colombia

${ }^{2}$ Technology and Nuclear Science, Bogotá, Colombia

Email de correspondencia: sartaj@javeriana.edu.co
} 


\section{INTRODUCCIÓN}

1 AN-R1 is a pool-type research reactor that was initially fueled with MTR-HEU enriched to $93 \%$ U-235 [1] and has been in operation since 1965 at $10 \mathrm{~kW}(\mathrm{t})$; the reactor was upgraded to $30 \mathrm{~kW}(\mathrm{t})$ in 1980. In 1997, General Atomics (GA) converted the HEU fuel to LEU fuel, TRIGA $\left(\mathrm{UzrH}_{1.65}\right)$ type, and upgraded the reactor power to $100 \mathrm{~kW}(\mathrm{t})$ [2].

This paper describes the thermal-hydraulic evaluations made for the IAN-R1 TRIGA reactor operating at $100 \mathrm{~kW}$ with cooling from natural convection flow around the fuel elements. To validate the calculations, the results have been compared with the thermal hydraulic analysis carried out by General Atomics (GA), who used the one-dimensional STAT code during the conversion of HEU fuel to LEU TRIGA fuel [3].

For a single channel of TRIGA IAN-R1 reactor operating at steady conditions, the exit coolant temperature, outlet coolant velocity, coolant flow rate, maximum wall temperature and fuel temperature are calculated. The maximum channel heat flux at which there is departure from nucleate boiling (DNB) and the transition to film boiling begins was also evaluated. All the values were obtained using the NATCON code [4].

\section{CALCULATIONS}

The TRIGA-LEU fuel is composed of a mixture of uranium and zirconium hydride $\mathrm{UZrH}_{1.65}$. The uranium loading is 12.75 wt \% of the fuel material, and ${ }^{235} \mathrm{U}$ is enriched to 19.7 \%. A $3.15 \mathrm{~mm}$ radius hole is drilled through the center of the fuel and filled with a solid zirconium rod. The fuel rods have a radius of $16.929 \mathrm{~mm}$ and a length of $381 \mathrm{~mm}$. Each fuel rod is clad with stainless-steel Type 304 with a $34.9 \mathrm{~mm}$ diameter [5]. For this analysis, it is assumed that the core is loaded with 54 rods.

The hydraulic flow parameters calculated for this work are listed in Table 1., and the channel used is a square array of fuel elements, as illustrated in Figure 1.

Table 1. Hydraulic flow parameters

\begin{tabular}{ll}
\hline Flow area & $527.7 \mathrm{~mm} 2 /$ elem. \\
\hline Wetted perimeter & $109.7 \mathrm{~mm} / \mathrm{elem}$. \\
\hline Hydraulic diameter & $19.2 \mathrm{~mm}$ \\
\hline Fuel element diameter & $34.9 \mathrm{~mm}$ \\
\hline Fuel surface area $(\mathrm{mm} 2)$ & $4.18 \times 104 \mathrm{~mm} 2$ \\
\hline
\end{tabular}
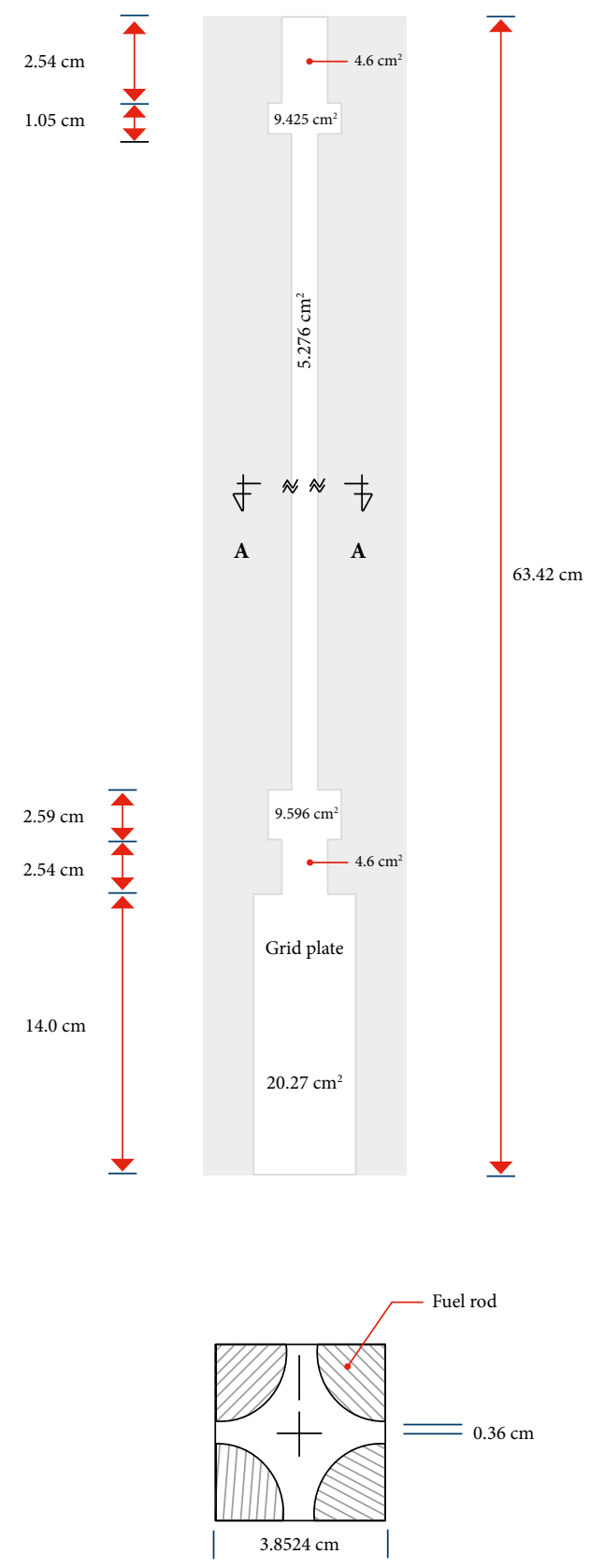

SECT. A A

Figure 1. Channel configuration and dimensions.

The NATCON code computes the natural convection conditions for a single channel in a research reactor that operates at steady conditions. Buoyant forces are computed based upon density differences between the channel and the pool, which are computed from the water temperature. The steady velocity is obtained from an iteration in which buoyant and friction forces are balanced [6]. 
The heat generation rate in the fuel element is distributed axially in a cosine distribution such that the maximum power generation in a fuel rod relative to the average rod power generation is 1.44 and the axial peak-to-average ratio is 1.26 , with an overall peak-to-average power density ratio of 1.8 [7].

Two correlations are used for the determination of temperatures for fuel, clad and coolant. The first is from Gnielinski, and the second is given by Colburn [8], which gives a higher value for the temperatures. The model was evaluated for 20 axial nodes through the fueled length with thermal conductivities for the fuel and cladding of $18 \mathrm{~W} / \mathrm{m}{ }^{\circ} \mathrm{C}$ and $15 \mathrm{~W} / \mathrm{m}^{\circ} \mathrm{C}$, respectively [7]. The inlet coolant temperature is $32.2^{\circ} \mathrm{C}$, and the distance from the pool surface to the bottom of the reactor is $4.22 \mathrm{~m}$. The heat flux at which there is a departure from nucleate boiling and the transition to film boiling begins was calculated with the correlation from Bernath [9].

\section{RESULTS}

Since the Reynolds number calculated for this work was 2.265 , the correlation given by Colburn was used together with the NATCON code to calculate the temperatures and heat flux as a function of the axial position for the maximum power channel. The temperatures of the fuel (length of $381 \mathrm{~mm}$ ), cladding and coolant are displayed in Figure 2 for $100 \mathrm{~kW}$ operation.

The results of the NATCON code analysis for the hottest fuel element when the IAN-R1 TRIGA reactor is operating at $100 \mathrm{~kW}$ are as follows: exit coolant temperature $43.7^{\circ} \mathrm{C}$, outlet coolant velocity $91.33 \mathrm{~mm} / \mathrm{s}$, flow rate $0.0477 \mathrm{~kg} / \mathrm{s}$, maximum wall temperature $120^{\circ} \mathrm{C}$, maximum fuel temperature $157^{\circ} \mathrm{C}$, and maximum heat flux $8.0 \mathrm{~W} / \mathrm{cm}^{2}$.

Figure 3 shows the maximum channel heat flux calculated with Bernath's correlation and the pool water temperature as a parameter. With an inlet water temperature of $32.2^{\circ} \mathrm{C}$, the maximum heat flux is $154 \mathrm{~W} / \mathrm{cm}^{2}$. For an inlet water temperature of $32.2^{\circ} \mathrm{C}$, the DNB ratio of the allowable heat flux to the maximum heat flux for the hottest fuel element is 19.25 .

Although the GA channel configuration does not include a grid plate, the comparison between GA results and this work establishes the following: the maximum heat flux ob-

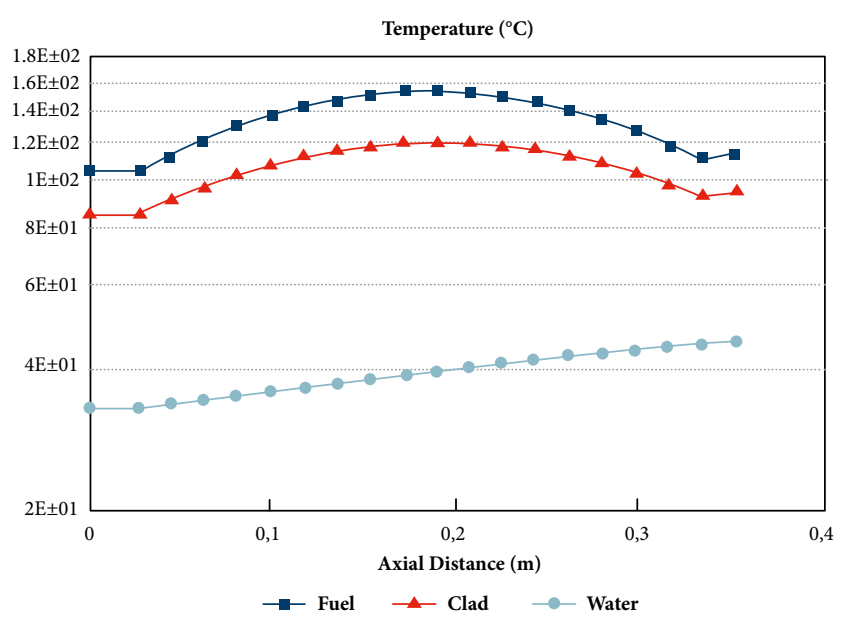

Figure 2. Temperatures of the fuel, cladding and coolant as a function of the axial position

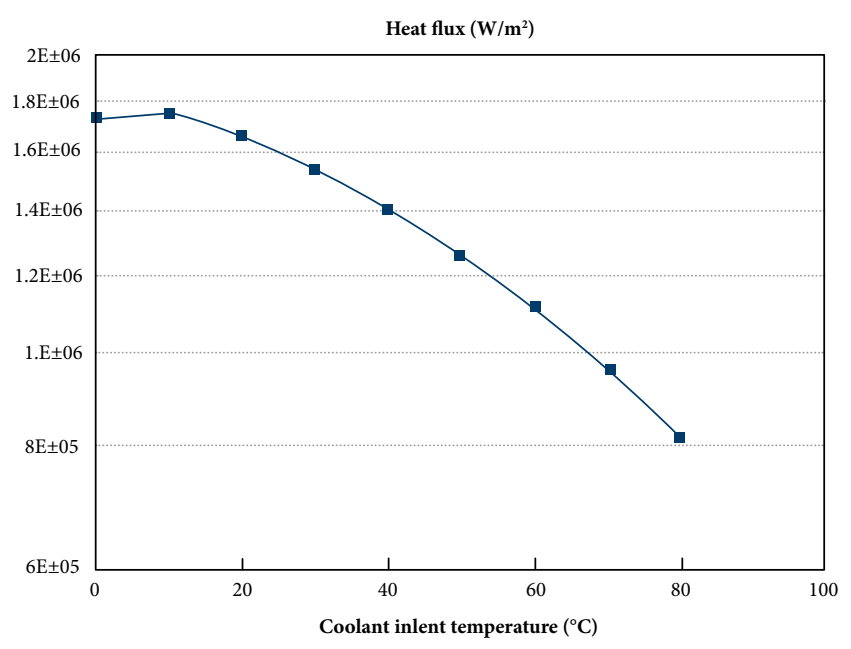

Figure 3. Maximum channel heat flux as a function of the pool water temperature

tained $\left(8.0 \mathrm{~W} / \mathrm{cm}^{2}\right)$ is the same for both, and the maximum wall temperature differs by $3.4 \%$. On the other hand, the exit coolant temperature and its velocity differ by $2.06 \%$ and $13.3 \%$, respectively.

\section{CONCLUSIONS}

The results of this study indicate that the NATCON code has an error of less than $3.4 \%$ for the maximum values with respect to the GA calculations. Regarding mean values, the difference between the GA values and this study are $13.3 \%$. For mean values, it is necessary to perform additional calculations including other channels in the core to improve the validation. 
The analysis indicates a safe operation of the IAN-R1 TRIGA reactor at $100 \mathrm{~kW}$ with 54 fuel rods in the core and $32 .{ }^{\circ} \mathrm{C}$ as the inlet water temperature. The maximum fuel temperatures calculated for the fuel and cladding are below the temperature safety limit of $1150{ }^{\circ} \mathrm{C}$ for $\mathrm{U}-\mathrm{ZrH}_{1.6}$ fuel when the cladding temperature is $500{ }^{\circ} \mathrm{C}$.

For the IAN-R1 TRIGA reactor at $100 \mathrm{~kW}$ with 54 fuel rods in the core, with $32.2{ }^{\circ} \mathrm{C}$ as the inlet water temperature and an overall peak-to-average power density ratio of 1.8 , the allowable heat flux corresponds to a maximum reactor power of $1930 \mathrm{~kW}$.

\section{ACKNOWLEDGMENTS}

This study was supported by the IAEA (International Atomic Energy Agency) and the Servicio Geológico Colombiano (before Ingeominas -Instituto Colombiano de Geología y Minería-). We thank Mrs. Alicia Vertullo for her helpful discussions.

\section{References}

[1] Lockheed Nuclear Products. Summary Report and Hazard Analysis. Nuclear Training Reactor for the Instituto de Asuntos Nucleares ER-688. Bogotá, Colombia, April 1964.

[2] J. A. Sarta, L. A. Castiblanco y J. Razvi, "Conversion of the IAN-R1 Reactor from MTR HEU Fuel to TRIGA LEU Fuel", Proceeding of 1997 International Meeting on Reduced Enrichment for Research and Test Reactors, Jackson Hole, p. 1-6, 1997.

Available: https://inis.iaea.org/search/search.aspx?orig_ $\mathrm{q}=\mathrm{RN}: 35089146$
[3] PETERSEN, J. F., STAT - A Fortran Program for Calculating the Natural Convection Heat Transfer - Fluid Flow in an Array of Heated Cylinders, General Atomics, July, 1989.

[4] R. S. Smith y W. L. Woodruff, "A computer code, NATCON, for the analyses of steady state thermal-hydraulics and safety margins in plate-type research reactors cooled by natural convection". Report ANL/RERTR/ TM-12, Argonne National Laboratory (1988). Available: https://www.osti.gov/biblio/6571231

[5] J. A. Sarta y L. A. Castiblanco, "Neutronic calculations in core conversion of the IAN-R1 from MTR to TRIGA LEU fuel", in Proceedings of the 2003 International Meeting on Reduced Enrichment for Research and Test Reactors, pp. 361-366, October 2003.

Available: https://inis.iaea.org/search/search.aspx?orig_ $\mathrm{q}=\mathrm{RN}: 35066258$

[6] M. Prakash, O. F. Turan y G. R. Thorpe, Program NATCON: For the numerical solution of buouyancy-driven laminar and turbulent flows in differentially heat cavities. July 2006. Available: https://core.ac.uk/download/ pdf/10826390.pdf

[7] General Atomics, "Safety analysis report for the Research Reactor conversion to TRIGA LEU fuel at Instituto de Ciencias Nucleares y Energias Alternativas", 1995.

[8] J. G. Collier y J. R. Thome, Convective Boiling and Condensation. Third Edition. Oxford University Press. USA 1996.

[9] Bernath L. "A theory of local-boiling burnout and its application to existing data", Chemical Engineering Progress Symposium, Series No. 30, Volume 56, 1960, pp.95-116. 